\section{JURNAL PARPPATINA

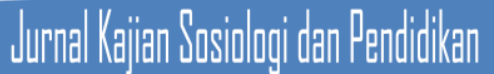

Jurnal Perspektif: Jurnal Kajian Sosiologi dan Pendidikan Vol. 4 No. 1 Tahun 2021

http://perspektif.ppj.unp.ac.id

Email: perspektif@ppj.unp.ac.id

ISSN: 2622-1748 (Online), 2684-902X (Print)

DOI: http://dx.doi.org/10.24036/perspektif.v4i1.384

\title{
Pemanfaatan Media Luar Ruang Sebagai Salah Satu Strategi Pemenangan Lisda Hendrajoni dalam Pileg 2019 Dapil Sumbar 1: Kajian Sosiologi Komunikasi Politik
}

\author{
Zeri Milyuta Putra ${ }^{1}$, Mohammad Isa Gautama ${ }^{2}$ \\ ${ }^{1,2}$ Universitas Negeri Padang \\ Email: zerimilyutaputra@gmail.com, migatama@ fis.unp.ac.id
}

\begin{abstract}
Abstrak
Latar belakang penelitian bermula dari kemenangan Lisda Hendrajoni dalam pemilihan umum legislatif periode 2019-2024 menjadi anggota DPR RI Komisi VIII Fraksi Partai Nasional Demokrat. Lisda Hendrajoni menggunakan media luar ruang sebagai salah satu strategi pemenangannya dalam pileg 2019. Penelitian ini bertujuan untuk menjelaskan pemanfaatan media luar ruang sebagai salah satu strategi pemenangan Lisda Hendrajoni dalam Pileg 2019 Dapil Sumbar 1. Teori yang digunakan dalam menganalisis penelitian ini adalah teori marketing politik yang dikemukakan oleh (Andrew Lock\& Phil Harris). Penelitian ini menggunakan pendekatan penelitian kualitatif tipe studi kasus intinsik. Teknik pemilihan informan adalah purposive sampling. Pengumpulan data dilakukan dengan cara observasi, wawancara dan studi dokumentasi. Hasil penelitian menunjukkan bahwa media yang digunakan dalam kampanye pemenangan Lisda Hendrajoni pada saat menjadi calon DPR-RI adalah pemakaian media luar ruang yang banyak ditemui seperti spanduk, baliho, billboard, kalender, stiker, dan contoh surat suara dikarenakan dapat terjangkau di semua masyarakat sampai ke kampungkampung, sehingga menggunakan media luar ruang merupakan media yang paling efektif untuk memperkenalkan kandidat ke masyarakat. Kemudian strategi pemenangan Lisda Hendrajoni juga melakukan pendekatan terhadap masyarakat melalui program sosial yang dilakukan, pembagian tim kampanye menjadi dua daerah pemilihan yang ada di Sumbar 1 yaitu di Pesisir Selatan yang diketuai oleh Kristian Rinaldo dan Sumbar 1 diluar Pesisir Selatan yang diketuai oleh Jefri Hidayat. Sehingga bisa memenangkan pemilihan umum legislatif DPR RI periode 2019-2024
\end{abstract}

Kata kunci: Kampanye, Media Luar Ruang, Strategi

\begin{abstract}
The research background originated from the victory of Lisda Hendrajoni in the 2019-2024 legislative elections to become a member of the Indonesian House of Representatives Commission VIII of the Democratic National Party Faction. Lisda Hendrajoni used outdoor media as one of his winning strategies in the 2019 legislative elections. This study aims to explain the use of outdoor media as one of the winning strategies for Lisda Hendrajoni in the 2019 Pileg Electoral District of West Sumatra 1. The theory used in analysing this research is political marketing theory proposed by Andrew Lock \& Phil Harris. This study used a qualitative research approach with an intinsic case study type. The technique of selecting informants is purposive sampling. Data collection was done by means of observation, interviews and documentation study. The results showed that the media used in Lisda Hendrajoni's winning campaign when he became a candidate for the DPR-RI was the use of outdoor media that was often encountered such as banners, billboards, billboards, calendars, stickers, and samples of ballot papers because they could be reached by all people down to villages, so using outdoor media is the most effective medium to introduce candidates to the community. Then the winning strategy of Lisda Hendrajoni also approached the community through the social program carried out, dividing the campaign team into two electoral districts in West Sumatra 1, namely Pesisir Selatan chaired by Kristian Rinaldo and West Sumatra 1 outside Pesisir Selatan chaired by Jefri Hidayat. So that it can win the DPR RI legislative general election for the 2019-2024 period.
\end{abstract}

Keywords: Campaign, Outdoor Media, Strategy 


\section{Pendahuluan}

Kajian marketing politik berkembang sejak tahun 1990 dipopulerkan dalam ranah akademik oleh ilmuan dari berbagai bidang ilmu marketing, komunikasi dan politik oleh Nicholas J. O'Shaughnessy. Teori Marketing politik bukan konsep untuk menjual partai politik atau kandidat presidensial ke pemilih, namun sebuah konsep yang menawarkan bagaimana sebuah partai politik atau kontestan bisa membuat program yang berhubungan dengan permasalahan aktual (O'Shaughnessy, 2001). Dalam marketing politik, yang perlu ditekankan adalah penggunaan pendekatan serta metode pemasaran untuk membantu politikus dan partai supaya lebih efisien serta efektif dalam membangun hubungan dua arah dengan konstituen dan masyarakat. Hubungan ini diartikan secara luas dari kontak fisik selama periode kampanye sampai dengan komunikasi tidak langsung melalui pemberitaan di media massa.

Pemasaran politik diidentifikasi kedalam 4P, yaitu Product (produk), promotion (promosi), price (Harga), Place (penempatan). Product (Produk), berarti kandidat dan gagasan-gagasan kandidat yang akan disampaikan kepada masyarakat. Produk ini berisi konsep, identitas ideologi dan isu politik yang menghasilkan image kandidat. Promotion (Promosi), pemilihan media dalam mempromosikan kandidat sesuai dengan kebutuhan masyarakat. Promotion yaitu pemilihan media bagi calon anggota legislatif dalam mempromosikan diri melalui media. Price (Harga), mencakup banyak hal dimulai dari ekonomi, psikologis, sampai citra nasional. Place (Penempatan), hubungan komunikasi antara kandidat dan masyarakat dengan fokus daerah pendistribusian product politik. Dalam artian daerah mana saja yang menjadi fokus marketing kandidat dalam meningkatkan perolehan suara. (Andrew, L., \& Phil, 1996)

Media luar ruang merupakan media yang berukuran besar dipasang di tempat-tempat terbuka seperti dipusat keramaian, pinggir jalan atau tempat-tempat khusus lainnya, seperti di gedung, pagar, tembok, dalam bus kota dan sebagainya (Tjiptono, 2008). Iklan media luar ruang merupakan iklan ditempatkan di luar ruang, biasanya banyak diletakkan di ruang kota, dengan mempertimbangkan kepadatan orang yang melalui ruang tersebut (Mulyana, 2010). Media luar ruang disebut juga media nirmassa (non massa) artinya media yang mempunyai kemampuan hampir sama dengan media massa dalam memperluas pesan periklanan, yakni mampu membuat pesan dilihat oleh banyak orang pada saat bersamaan (Kriyantono, 2013). Strategi adalah arah atau jalan yang akan ditempuh organisasi dalam rangka menjalankan misinya untuk menuju pencapaian misi (Muljono, 2012). Selanjutnya menurut ahli sosiologi Selznick mengatakan bahwa strategi yang baik adalah strategi yang memuat nilai-nilai para anggotanya sehingga mereka merasa terikat dengan tujuan perusahaan dan dapat juga menjadi dorongan secara terus menerus bagi anggotanya (Haryono, 2019).

Hakikat Pemilu merupakan pemilihan kepala daerah sebagai sarana pelaksanaan kedaulatan rakyat pada tiap wilayah baik provinsi maupun kabupaten/kota dengan cara pengembangan sarana demokrasi dan kedaulatan rakyat dalam Negara Indonesia sehingga kepala daerah dan wakil kepala daerah dipilih langsung oleh rakyat Indonesia (Iqbal, 2012). Pada pelaksanaan pemilu pada tahun 2019 yang lalu terdapat 20 partai politik secara nasional 
yang berkontestasi dalam merebut kekuasaan dalam menduduki kursi di parlemen. Perebutan kekuasaan tersebut semakin terlihat dengan adanya strategi yang dilakukan dalam mencari dukungan politik. Pada pemilu legislatif di Sumatra Barat terdapat calon anggota anggota legislatif yang akan berkontestasi dalam pemilihan legislatif DPR RI pada daerah pilihan Sumbar 1 yang merupakan kandidat perempuan berasal dari Kabupaten Pesisir Selatan yaitu Lisda Hendrajoni. Beliau juga seorang istri Bupati Pesisir Selatan Bapak Hendrajoni yang berhasil memenangkan pemilihan Legislatif dengan suara terbanyak dari partai Nasdem yaitu sebanyak 37.326 suara. Berikut tabel data tentang jumlah perolehan suara pada pemilu legislatif 2019 dapil Sumbar 1 dari partai Nasdem perdaerah pemilihan:

Tabel 1. Daftar Nama Calon Pemilu Legislatif 2019 dari Partai Nasdem Dapil Sumbar 1

\begin{tabular}{|c|c|c|c|c|c|c|c|c|c|c|c|c|}
\hline \multicolumn{12}{|c|}{ Rincian } & \multirow{2}{*}{$\begin{array}{l}\text { Jumlah } \\
\text { Akhir }\end{array}$} \\
\hline & $\begin{array}{l}\text { Pesisir } \\
\text { Selatan }\end{array}$ & Solok & Sijunjung & $\begin{array}{l}\text { Tanah } \\
\text { Datar }\end{array}$ & $\begin{array}{l}\text { Kepulauan } \\
\text { Mentawai }\end{array}$ & Dharmasraya & $\begin{array}{l}\text { Solok } \\
\text { Selatan }\end{array}$ & $\begin{array}{l}\text { Kota } \\
\text { Padang }\end{array}$ & $\begin{array}{l}\text { Kota } \\
\text { solok }\end{array}$ & $\begin{array}{c}\text { Kota } \\
\text { Sawahlunto }\end{array}$ & $\begin{array}{c}\text { Kota } \\
\text { Padang } \\
\text { panjang }\end{array}$ & \\
\hline \multicolumn{13}{|l|}{$\begin{array}{l}\text { Nama Partai } \\
\text { dan Caon }\end{array}$} \\
\hline Partai Nasdem & 2.454 & 1.822 & 1.330 & 1.208 & 367 & 823 & 1.080 & 2.585 & 234 & 369 & 218 & 12.490 \\
\hline $\begin{array}{l}\text { 1. ENDRE } \\
\text { SAIFOEL }\end{array}$ & 2.031 & 2.529 & 16.705 & 1.440 & 693 & 1.507 & 1.059 & 4.200 & 515 & 1.534 & 136 & 32.349 \\
\hline $\begin{array}{l}\text { 2. DRS. } \\
\text { SYAMSU } \\
\text { RAHIM }\end{array}$ & 986 & 10.357 & 1.090 & 464 & 348 & 528 & 618 & 1.657 & 2.751 & 1.906 & 95 & 20.800 \\
\hline $\begin{array}{l}\text { 3. HJ. LISDA } \\
\text { HENDRAJONI, } \\
\text { SE., MMTr. }\end{array}$ & 29.513 & 679 & 545 & 594 & 148 & 1.431 & 1.001 & 2.611 & 88 & 634 & 82 & 37.326 \\
\hline $\begin{array}{l}\text { 4. SURIATI } \\
\text { MUZNI } \\
\text { ZAKARIA }\end{array}$ & 900 & 1.359 & 185 & 146 & 88 & 219 & 14.157 & 740 & 183 & 54 & 40 & 18.071 \\
\hline $\begin{array}{l}\text { 5. Dr. FAUZI } \\
\text { BAHAR }\end{array}$ & 2.101 & 1.237 & 557 & 672 & 168 & 395 & 680 & 14.867 & 391 & 296 & 183 & 21.547 \\
\hline $\begin{array}{l}\text { 6. DELVIA } \\
\text { INDRA } \\
\text { RAJUDDIN }\end{array}$ & 114 & 112 & 34 & 58 & 24 & 25 & 66 & 203 & 10 & 186 & 10 & 842 \\
\hline $\begin{array}{l}\text { 7. PUJI } \\
\text { CHEGANA }\end{array}$ & 99 & 141 & 61 & 52 & 21 & 14 & 48 & 194 & 24 & 991 & 17 & 1.662 \\
\hline $\begin{array}{l}\text { 8. SHOFWIM } \\
\text { SHOFWAN, } \\
\text { S.PSI., MBA }\end{array}$ & 95 & 45 & 42 & 78 & 16 & 62 & 22 & 280 & 8 & 17 & 17 & 682 \\
\hline
\end{tabular}

Sumber: KPU Provinsi Sumatera Barat

Kemenangan Lisda Hendrajoni dalam Pileg 2019 yang lalu tidak lepas dari strategi yang dilakukan ketika berkampanye. Banyak hal yang dilakukan demi mencari dukungan kepada masyarakat, mulai dari melakukan program sosial berupa memberi bantuan kepada masyarakat di bawah garis kemiskinan sampai kampanye tatap muka. Dalam suatu pertarungan pada kontestasi politik sangat diperlukan strategi untuk memperoleh kemenangan dan menghindari kekalahan sehingga strategi menjadi penentu utama dari keberhasilan suatu kegiatan (Jaya, 2015). Salah satu strategi yang dilakukan atas kemenangan Lisda Hendrajoni dalam pemilihan legislatif 2019 yang lalu adalah pemanfaatan media luar ruang. Dinamika komunikasi politik pada masyarakat diberbagai tahapan penyelenggaraan pemilihan umum akan meningkat seiring dengan meningkatnya kesiapan partai politik maupun kandidat perseorangan sebagai kontestan yang akan bertarung pada pemilihan umum dalam upayanya untuk meraih kemenangan dengan cara usaha-usaha untuk menarik perhatian dan dukungan publik (Sutarso, 2011). Hal ini merupakan alasan dari maraknya media luar 
ruang yang tersebar sewaktu kampanye yang dimanfaatkan oleh tim kemenangan atau bisa disebut dengan tim kampanye dari masing-masing calon anggota legislatif yang berkontestasi dalam pileg 2019 yang lalu. Dari semua anggota legislatif terpilih sebagai anggota dewan yang dipilih langsung oleh masyarakat sangat berbanding lurus dengan banyaknya media luar ruang yang dipasang ditiap titik strategis atau ditiap-tiap persimpangan yang ada di Sumatera Barat.

Dalam hal ini media luar ruang bukan saja sebagai sumber informasi politik melainkan kerap menjadi faktor pendorong (trigger) terjadinya perubahan politik. Strategi kampanye merupakan proses menyampaikan pesan dari kandidat untuk mempengaruhi masyarakat dengan cara apapun sehingga menjadikan masyarakat pemilih berpihak kepada kandidat sedangkan pesan politik adalah pesan yang disampaikan mulai dari dalam bentuk poster, spanduk, baliho, diskusi, sampai pada selebaran yang dibagikan kepada pemilih (Alkindi, 2019). Strategi yang dilakukan dalam mengiklankan atau mempromosikan dirinya sebagai calon anggota legislatif kepada masyarakat tersebut tujuannya adalah untuk mendapatkan suara dan dukungan masyarakat serta memenangkan pemilu, salah satu taktiknya dalam mendapatkan suara rakyat tersebut adalah melalui media luar ruang dengan memasangkan spanduk, baliho, dan billboar sehingga ketika masyarakat yang belum mengetahui seorang calon pemimpin atau calon dari pemilu 2019 yang lalu, dengan adanya media luar ruang yang dilihat disepanjang jalan masyarakat akan menjadi tahu siapa orang yang akan dipilihnya. Dalam berkampanye dapat dilihat bahwa menggunakan media luar ruang adalah salah satu strategi untuk melibatkan masyarakat dalam berkampanye. Dari tahun ke tahun, kegiatan Pemilu selalu diwarnai dengan "perang" spanduk pasangan calon yang akan bertarung (Darmawan, 2018). Apa yang ditampilkan dalam spanduk, umumnya berisi janji-janji pasangan calon yang digunakan untuk meraih dukungan pada saat pemilihan berlangsung nantinya.

Dengan adanya media luar ruang yang dipakai dalam berkampanye dan mensosialisasikan diri calon yang akan berkontestasi dapat merekrut atau melibatkan orang untuk menjadi tim sukses, keamanan, dan menjadi relawan seperti membelikan bahan untuk membuat media luar ruang, pembuatan spanduk, baliho dan billboard sampai pada titik pemasangan dan keamanan dalam pemasangan media luar ruang tersebut. Permasalahan dalam penelitian ini adalah dikarenakan kemenangan Lisda Hendrajoni dipengaruhi salah satunya oleh masifikasi media luar ruang. Terlihat bahwa media luar ruang sangat mempengaruhi pilihan pemilih, ditengah-tengah masyarakat sekarang sudah mengenal dan akrab dengan media online, ternyata masih memilih media luar ruang dalam berkampanye dan media luar ruang itu masih melibatkan masyarakat luas dalam aktivitas kampanye para calon yang ikut dan terpilih dalam pemilu 2019 yang lalu. Berdasarkan permasalahan di atas maka tujuan artikel ini adalah untuk menjelaskan strategi kampanye dalam memanfaatkan media luar ruang sebagai salah satu strategi pemenangan Lisda Hendrajoni pada pemilihan legislatif 2019 daerah pemilihan Sumatera Barat 1: Kajian Sosiologi Komunikasi Politik.

Beberapa Penelitian yang relevan dalam penelitian penulis dapat dilihat pada penelitian yang dilakukan oleh Sabiqul Iman mahasiswa Program Pascasarjana Magister Ilmu Administrasi Fakultas Ilmu Sosial dan Ilmu Politik Universitas Lampung dengan judul "Strategi Pemanfaatan Media Luar Ruang dalam Kontestasi Politik di Provinsi Lampung". Hasil penelitian yaitu dalam kontestasi politik di Provinsi Lampung khususnya Daerah Pemilihan Kota Bandar Lampung, media luar ruang masih menjadi media yang relevan untuk promosi kandidat. Di samping itu baliho dianggap sebagai media promosi luar ruang yang lebih baik/tepat dibandingkan beberapa media luar ruang lainnya, yang menjadikan baliho 
lebih baik atau tepat adalah bentuk, tampilan baliho dan lokasi penempatan baliho (Iman, 2018).

Kemudian penelitian Suryatna mahasiswa Fakultas Ilmu Politik dan Ilmu Komunikasi Universitas Djuanda dengan judul "Pengaruh Terpaan Media Iklan Politik Terhadap Perilaku Pemilih Pemula". Hasil penelitian yaitu memperlihatkan bahwa perilaku memilih dari para pemilih pemula dipengaruhi oleh terpaan media iklan politik, pesan iklan politik, serta oleh terpaan media iklan poitik dan pesan iklan politik (Suryatna, 2011).

Selanjutnya penelitian Hasanuddin dan Amir Syamsuadi dosen Jurusan Ilmu Pemerintahan Fakultas Ilmu Sosial dan Ilmu Politik Universitas Riau dengan Judul "Pemetaan Media Luar Ruang pada Pelaksanaan Pemilihan Gubernur dan Wakil Gubernur Riau (Pilgubri) Tahun 2013 di Kota Pekanbaru". Hasil penelitian yaitu media luar ruang yang digunakan oleh kandidat bakal calon maupun calon Gubernur dan wakil Gubernur di Provinsi Riau 2013 adalah dalam bentuk billboard, balliho, spanduk dan banner. Media luar ruang tersebut banyak dipasang pada kawasan strategis yang ada di Kota Pekanbaru seperti kawasan persimpangan, kawasan pusat perbelanjaan, kawasan jembatan, kawasan objek wisata, dan kawasan perhotelan (Syamsuadi, 2013).

Berdasarkan hasil penelitian penulis dengan hasil penelitian Iman Sabiqul (2018), Suryatna (2011) dan Hasanuddin dan Amir (2013) dapat disimpulkan bahwa pentingnya media luar ruang dalam berkampanye pada pemilihan legislatif untuk mempromosikan kandidat yang dipasang pada kawasan yang strategis yang ada di daerah pemilihan.

\section{Metode Penelitian}

Penelitian ini bersifat deskriptif dengan pendekatan kualitatif tipe studi kasus intrinsik, yaitu peneliti mencoba menggambarkan dan mengungkap semua fenomena, gejala dan kejadian secara apa adanya dalam bentuk keterangan-keterangan. Hal ini seiring dengan pendapat Yusuf mengatakan bahwa penelitian kualitatif adalah suatu strategi inguiry yang menekankan pencairan makna, pengertian, konsep, karakteristik, gejala, simbol, maupun deskripsi tentang suatu fenomena (Yusuf, 2014). Lokasi penelitian ini dilakukan di salah satu daerah pemilihan Sumatra Barat 1 yaitu Kabupaten Pesisir Selatan. Pemilihan informan memakai teknik purposive sampling dengan jumlah informan sebanyak 3 orang yaitu Lisda Hendrajoni (Anggota Legislatif DPR RI terpilih dari Partai Nasdem periode 2019-2024), Jefri Hidayat Ketua Tim Pemenangan Sumbar 1 (Diluar Pesisir Selatan) dan Kristian Rinaldo Ketua Tim Pemenangan Pesisir Selatan. Teknik pengumpulan data dilakukan dengan cara observasi, wawancara mendalam (indepth interview) dan studi dokumentasi. Untuk memeriksa keabsahan data dalam penelitian ini maka penulis menggunakan teknik triangulasi data. Teknik analisis data menurut Matthew B. Milles dan A. Michael Huberman yaitu Data Reduction (Reduksi Data), Data Display (Penyajia Data), dan Conclusion Drawing/ Verification (Penarikan Kesimpulan).

\section{Hasil dan Pembahasan}

\section{Strategi Pemenangan Lisda Hendrajoni pada Pemilihan Legislatif DPR RI Periode 2019-2024}

Strategi kemenangan Ibu Lisda Hendrajoni dalam pemilihan umum legisalatif DPR RI daerah pemilihan Sumatra Barat1 pada periode 2019-2024 yaitu: 


\section{Pendekatan Terhadap Masyarakat}

Yang menjadi strategi utama sebelum memanfaatkan media luar ruang untuk mendapatkan dukungan dari masyarakat dalam pemilihan umum legislatif DPR RI daerah pemilihan Sumatra Barat 1 oleh Lisda Hendrajoni adalah pendekatan kepada masyarakat. Di Pesisir Selatan banyak yang maju menjadi caleg maka sangat diperlukan suara dari luar Pesisir Selatan sehingga perlu pendekatan terhadap masyarakat dengan mengadakan banyak pertemuan-pertemuan. Berdasarkan hasil wawancara dengan Bapak Kristian Rinaldo bahwa:

“...Kalau media luar ruang itukan alat peraga cuma untuk ke masyarakat kan kegiatan kita mengunjungi kelompok-kelompok masyarakat lalu mensosialisasikan atau mengkampanyekan ibuk, kegiatan ibuk, tentang status ibuk sebagai ketua PKK atau istri bupati, tentang kepedulian ibuk kepada masyarakat, dan dalam kegiatan ibuk ada namanya DMD (dunsanak mambantu dunsanak), ada program bedah rumah, bantuan kursi roda, tongkat, jadi kami mengkampanyekan semua kegiatan ibuk lalu menyampaikan target ibuk nanti kalau jadi anggota DPR RI seperti apa, jadi kami berusaha menjelaskan itu semua kepada masyarakat..." (Wawancara, tanggal 08 November 2020)

Berdasarkan hasil wawancara dengan Bapak Kristian Rinaldo dapat disimpulkan bahwa di Kabupaten Pesisir Selatan tim berusaha untuk memperkenalkan Lisda Hendrajoni ke masyarakat seperti memsosialisasikan kegiatan sosial yang pernah dilakukan oleh Lisda Hendrajoni serta menjelaskan dan memberikan pemahaman kepada masyarakat target Lisda Hendrajoni kalau terpilih menjadi anggota DPR RI, semua dimaksimalkan oleh tim di Kabupaten Pesisir Selatan dengan alasan Pesisir Selatan adalah Basisnya Lisda Hendrajoni.

\section{Pembagian Tim Kampanye}

Ada strategi kampanye yang dilakukan baik oleh Lisda Hendrajoni yang ada di Pesisir Selatan dan di Sumatra Barat 1. Pertama mengenai tim kampanye, Lisda Hendrajoni membagi tim kampanye menjadi dua daerah yang pertama yaitu di Pesisir Selatan dan di Sumatra Barat 1 (Luar Pesisir Selatan). Ada alasan mengapa Lisda Hendrajoni membagi tim kampanye menjadi dua, berdasarkan hasil wawancara dengan Ibu Lisda Hendrajoni selaku Anggota DPR RI Komisi VIII Fraksi Partai Nasdem menjelaskan bahwa:

“...Saya membentuk tim itu ada dua, yang pertama tim khusus Pesisir Selatan diketuai oleh Kristian Rinaldo dan tim Sumbar 1 di luar Pesisir Selatan diketuai oleh Jefri Hidayat. Kita kan punya sebelas Kabupaten/kota, jadinya kabupaten Pesisir Selatan itu sendiri timnya yang memang sudah ada di Pesisir Selatan. Di luar Pesisir Selatan saya bentuk lagi karena saya kan baru juga dan jaringannya itu ada jaringan partai, ada jaringan yang memang relawan. Tapi kalau partai kini saya juga cuma beberapa orang yang memang merapat kepada saya karena disitu ada incumbent di partai nasdem kemudian ada tokoh-tokoh lain jadi berbagibagilah di partai Nasdem sendiri yang mana ke kita. Jadi ada di Padang beberapa titik yang bisa saya jalan sama mereka tapi di kabupaten kota lain juga ada cuma tidak terlalu banyak itu saja sih dari partai, lebih ke relawan saja selain itu saya juga ketua ikatan pengusaha muslim Indonesia binaan saya di luar Pesisir Selatan juga kita manfaatkan..." (Wawancara, tanggal 20 Oktober 2020)

Berdasarkan hasil wawancara dengan Ibu Lisda Hendrajoni bahwa dalam strategi kampanye dalam pembentukan tim pemenangan di Pesisir Selatan dan di Sumbar 1 diluar 
Pesisir Selatan dibagi menjadi dua dikarenakan Pesisir Selatan adalah basisnya suara Lisda Hendrajoni yang tinggal di Pesisir Selatan dan harus dimanfaatkan sebaik mungkin sehingga Tim kampanye dibagi menjadi dua daerah di dapil Sumbar 1 yaitu di Pesisir Selatan di ketuai oleh Kristian Rinaldo dan di Sumbar 1 diluar Pesisir Selatan di ketuai oleh Jefri Hidayat.

\section{Memanfaatkan Media Luar Ruang}

Pemakaian media luar ruang pada saat kampanye banyak ditemui dari kampanye Lisda Hendrajoni dalam Pileg 2019 kemaren, seperti yang diungkapkan langsung oleh Ibu Lisda Hendrajoni yang menjelaskan bahwa alat peraga kampanye (APK) sangat diperlukan selain itu banyak pertemuan-pertemuan yang dilakukan baik di Pesisir Selatan maupun diluar Pesisir Selatan. Media luar ruang sangat besar manfaatnya kalau untuk DPR RI karena banyak orang yang tidak kenal dengan calon-calon anggota legislatif kecuali dikampungnya sendiri. Kalau diluar Pesisir Selatan banyak yang tidak kenal maka dimanfaatkan baliho, spanduk, billboard yang besar-besar. Dengan adanya baliho, spanduk dan billboard merupakan salah satu cara memperkenalkan diri kepada masyarakat.

Selanjutnya Bapak Kristian Rinaldo selaku Ketua Tim pemenangan Lisda Hendrajoni di Pesisir Selatan juga menjelaskan bahwa:

“...Kalau baliho pemasangannya itu pasti di tempat-tempat strategis seperti jalan, pasar, cuma yang pasti ini di Pesisir Selatan ada 15 kecamatan jadi memang tempat-tempat strategis di tepi jalan dan pasar-pasar mulai dari barung-barung balantai sampai ke silaut memang kita pasang..." (Wawancara, tanggal 08 November 2020)

Berdasarkan hasil wawancara dengan Ibu Lisda Hendrajoni dan bapak Kristian Rinaldo bahwa strategi yang dilakukan dalam memanfaatkan media luar ruang dipasang pada beberapa titik dan ditempat-tempat strategis. Pemasangan media luar ruang di daerah perkotaan seperti spanduk dan baliho tidak banyak dipasang karena tim mensurvei serta pemasangaannya pun berdasarkan hasil dari pemantauan tim dilapangan. Khusus di Pesisir Selatan pemasangan spanduk dan baliho penempatannya tersebar di 15 kecamatan yang ada di Pesisir Selatan sehingga sebelum dipasang spanduk dan baliho disuatu daerah terlebih dahulu tim memetakan daerah tersebut.

Berbeda halnya strategi yang dilakukan dalam memanfaatkan media luar ruang oleh tim pemenangan yang ada di daerah pemilihan Sumatra Barat 1 di luar Pesisir Selatan yang disampaikan oleh Bapak Jefri Hidayat selaku ketua tim pemenangan di daerah pemilihan Sumatra Barat 1 di luar Pesisir Selatan mengatakan bahwa upaya yang dilakukan oleh tim pemenangan Lisda Hendrajoni dalam memanfaatkan media luar ruang dikarenakan ruang media sosial itu sempit tim memilih untuk hentikan main-main dimedia sosial kecuali diberanda media sosial masing-masing karena kalau main dimedia sosial pasti dibully oleh pendukung Prabowo. Jadi dimanfaatkanlah media luar ruang seperti spanduk, baliho, billboard dan itupun tidak ditempat-tempat ruang publik dan tidak di daerah ramai misalnya di daerah perkotaan tapi hanya masuk di kampung-kampung. Untuk kampanye Lisda Hendrajoni sangat efektif karena dinamikanya politik, tim tidak ada main menyebar-nyebar APK sembarangan, kalau ada tim baru dipasang baliho dan spanduk disuatu daerah tersebut. Khusus partai Jokowi dan pendukung Jokowi tidak ada dampaknya media luar ruang yang dipasang karena pemasangan dikampung A hanya sekitar kampung A saja dampaknya.

Berikut beberapa media yang digunakan oleh Ibu Lisda Hendrajoni dalam berkampanye pada saat pemilihan legislatif 2019: 


\section{Spanduk}

Ibu Lisda Hendrajoni menjelaskan bahwa alasan masih memanfaatkan media luar ruang berjenis spanduk dalam kampanye beliau adalah kalau dibandingkan dengan media sosial hanya beberapa persen saja orang yang melihat. Akan tetapi kalau media luar ruang seperti spanduk menjangkau semua orang di kampung-kampung baik itu petani maupun nelayan yang mereka belum aktif di media sosial. Sehingga dapat dikatakan bahwa media sosial itu lebih kepada milenial orang-orang yang sudah paham hal itu atau orang-orang terpelajar. Tapi dilihat bahwa kenyataannya penduduk di Pesisir Selatan maupun di luar Pesisir Selatan masih banyak orang-orang yang memang istilahnya belum mengenal media sosial karena belum ada sinyal dan kendala lainnya.

Gambar 1 di bawah ini merupakan bentuk media luar ruang Lisda Hendrajoni jenis Spanduk yang dipasang di rumah warga dan untuk kampanye.

\section{Baliho}

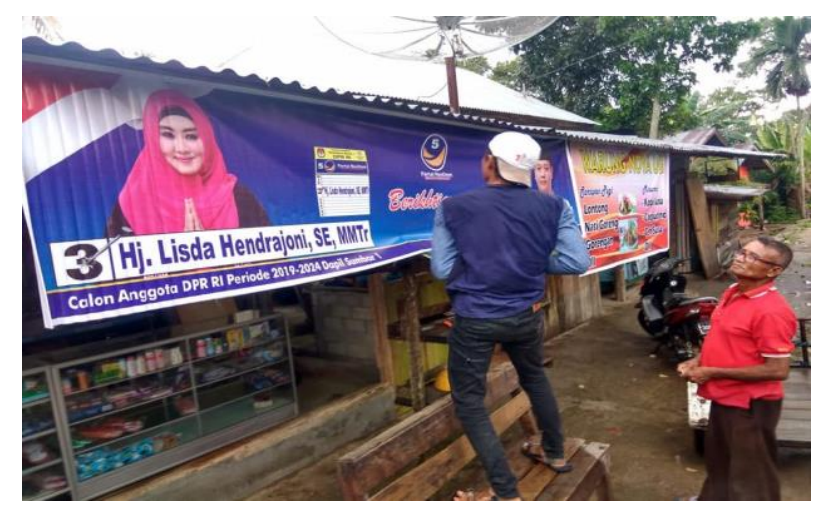

Gambar 1. Tim sukses memasang spanduk

Berdasarkan hasil wawancara dengan Bapak Jefri Hidayat selaku ketua tim pemenangan di daerah pemilihan Sumatra Barat 1 di luar Pesisir Selatan bahwa baliho di pasang harus memiliki tanda-tanda, yang pertama harus ada tim disuatu daerah tersebut dan daerah tersebut di survei dulu apakah menerima atau tidak. Jika di suatu daerah tersebut memiliki tim yang ada di sana dan daerah tersebut menerima maka dipasangkan baliho. Selanjutnya baliho sedikit dipasangkan di luar-luar seperti jalanan tapi banyak dipasangkan baliho di daerah pinggiran.

Gambar 2 di bawah ini merupakan bentuk media luar ruang Lisda Hendrajoni jenis Baliho yang dipasang untuk kampanye.

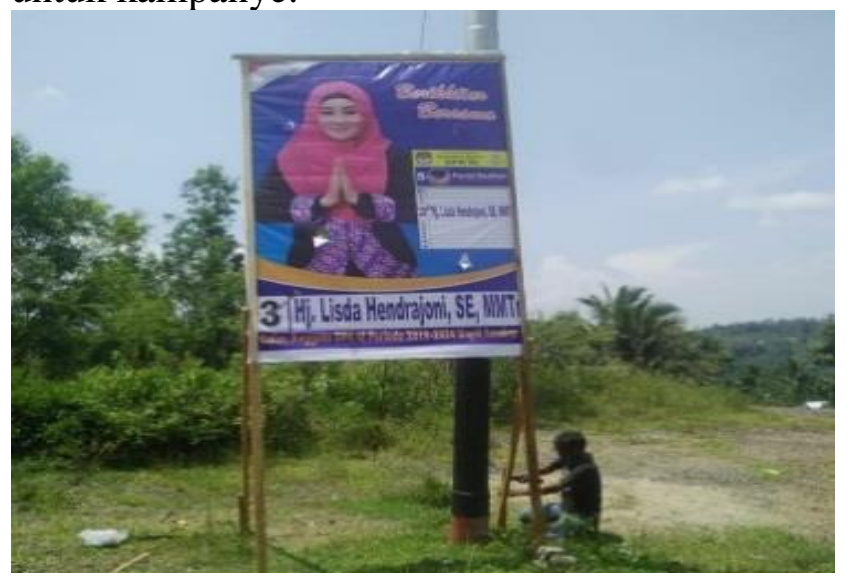

Gambar 2. Tim sukses memasang Baliho 


\section{Billboard}

Media luar ruang berjenis billboard juga dimanfaatkan oleh Ibu Lisda Hendrajoni dalam kampanye pada pileg 2019 kemaren. Billboard merupakan periklanan outdoor yang paling utama. Billboard dirancang dengan tujuan memperkenalkan nama merek. Billboard biasanya terpampang di jalan raya yang lalu lintas ramai. Iklan yang menempel pada sekarang ini lebih banyak dibuat menggunakan teknologi komputer atau teknologi digital. Bahan yang digunakan untuk mencetak iklan dengan teknologi digital ini biasanya tahan air dan juga panas.

Gambar 3 di bawah ini merupakan bentuk media luar ruang Lisda Hendrajoni jenis Billboard yang dipasang untuk kampanye.

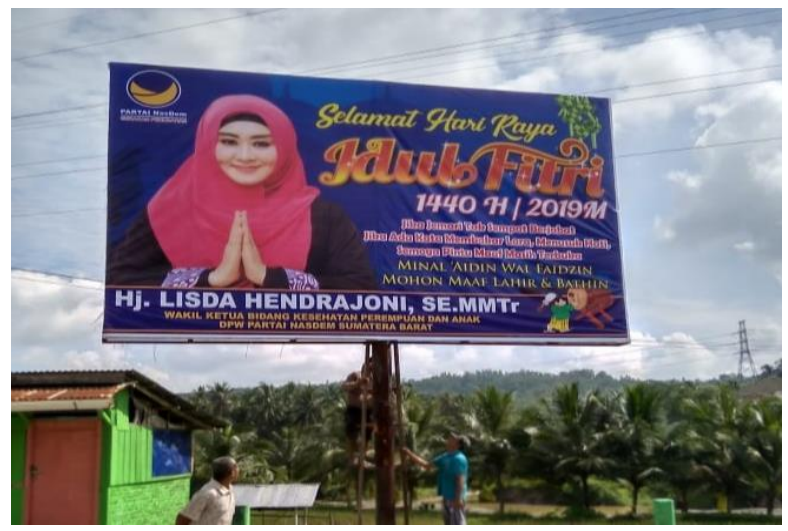

Gambar 3. Tim sukses memasang Billboard

\section{Kalender}

Kalender yang digunakan dalam kampanye lisda hendrajoni yaitu kalender yang diberikan kepada masyarakat didalamnya terdapat foto Ibu Lisda Hendrajoni dan berisi nomor urut caleg. Dengan adanya kalender yang diberikan kepada masyarakat menjadikan masyarakat dapat melihat foto Lisda Hendrajoni dalam pileg 2019 nomor urut 3 yang dibagikan kepada masyarakat untuk bersosialisasi maupun memperkenalkan diri kepada masyarakat. Cara demikian merupakan salah satu bentuk strategi yang memanfaatkan media luar ruang untuk berkampanye.

Gambar 4 di bawah ini merupakan bentuk media luar ruang Lisda Hendrajoni jenis Kalender yang dipasang untuk kampanye.

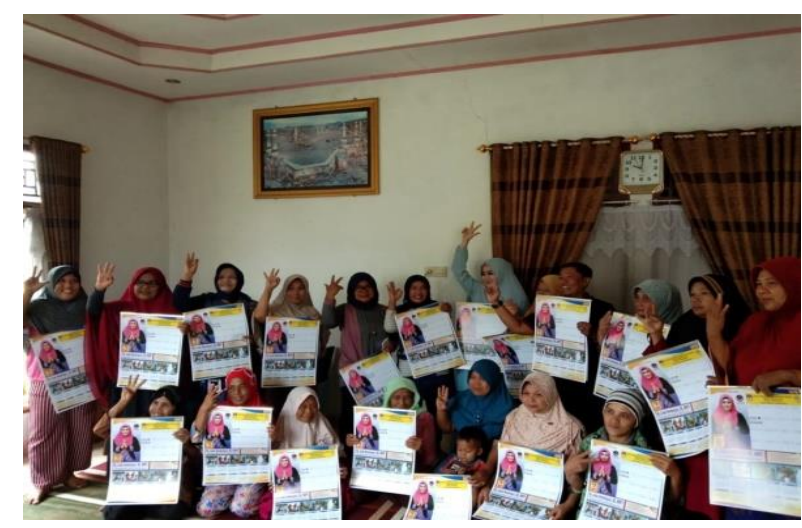

Gambar 4. Kalender Berisikan Foto dan Kegiatan Ibu Lisda Hendrajoni Yang Dibagikan Kepada Masyarakat 


\section{Stiker}

Kampanye Ibu Lisda Hendrajoni juga memanfaatakn stiker sebagai media untuk memperkenalkan dan mensosialisasikan dirinya sebagai caleg DPR RI dan dibagikan kepada masyarakat yang mendukungnya. Gambar 5 di bawah ini merupakan bentuk media luar ruang Lisda Hendrajoni jenis Stiker yang dibagikan kepada pendukungnya dalam berkampanye.

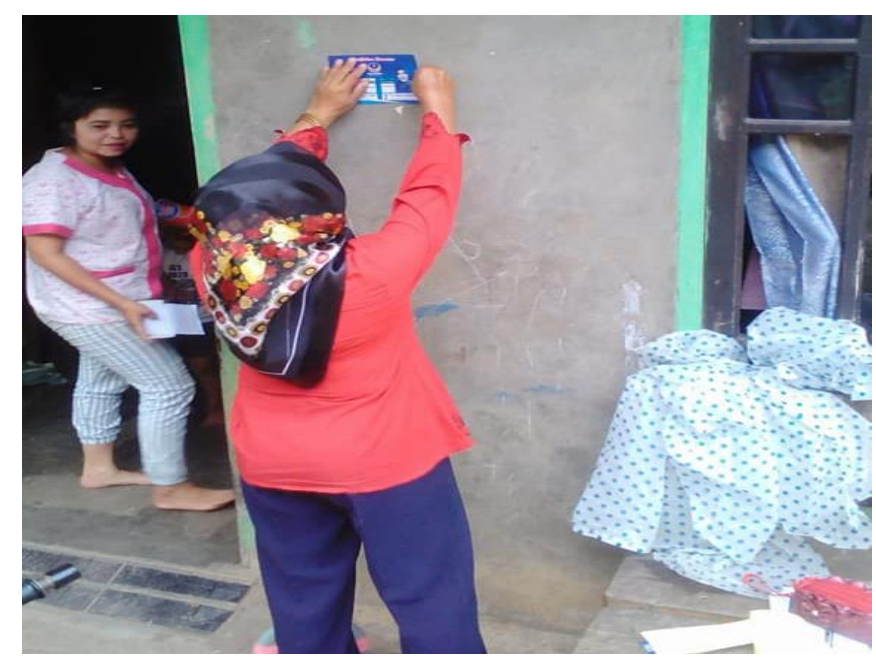

Gambar 5. Tim sukses menempel Stiker dirumah warga

\section{Contoh Surat Suara}

Contoh surat suara merupakan suatu bentuk surat suara yang digunakan saat pemilihan berlangsung. Media ini digunakan oleh tim sukses untuk mensosialisasikan Ibu Lisda Hendrajoni dalam Pileg 2019 dan disosialisasikan kepada masyarakat dengan cara mensosialisasikan kepada pemilih letak dan cara mencoblos calon pilihan mereka yaitu Lisda Hendrajoni yang mana pada dasarnya masyarakat sangat awam sampai tidak tau bagaimana menentukan yang mana contoh surat suara untuk mencoblos anggota DPR RI karena disetiap kertas memiliki warna tertentu di tiap-tiap surat suara tersebut.

Gambar 6 di bawah ini merupakan bentuk media luar ruang Lisda Hendrajoni jenis Contoh Surat Suara yang disosialisasikan kepada pendukungnya dalam berkampanye.

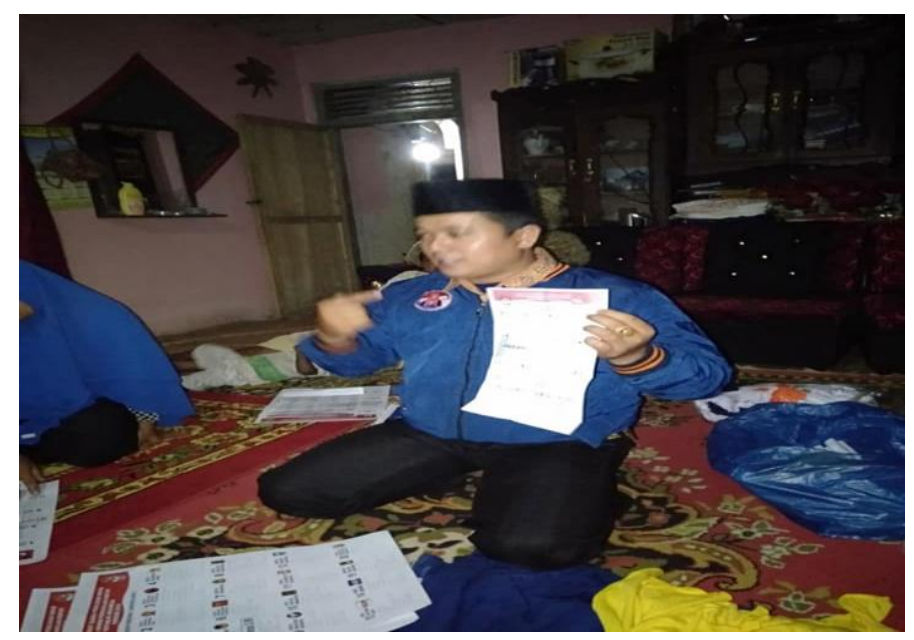

Gambar 6. Tim sukses mensosialisasikan melalui contoh surat suara 
Zeri Milyuta Putra, Mohammad Isa Gautama Pemanfaatan Media Luar Ruang Sebagai Salah Satu Strategi Pemenangan Lisda Hendrajoni Dalam Pileg 2019 Dapil Sumbar 1: Kajian Sosiologi Komunikasi Politik

\section{Analisis Teori Marketing Politik Terhadap Pemenangan Lisda Hendrajoni dalam Pemilihan Legislatif DPR RI}

Berdasarkan hasil penelitian di atas, teori Marketing Politik relevan dengan penelitian ini. Berikut deskripsi Marketing Politik terhadap pemenangan Lisda Hendrajoni dalam pemilihan legislatif DPR RI yang telah dianalisis oleh peneliti kedalam teori Political Marketing Andrew Lock \& Phil Harris diidentifikasi kedalam 4P yaitu Product (Produk), Promotion (Promosi), Price (Harga), Place (Penempatan) secara mendalam. Marketing Politik terhadap pemenangan Lisda Hendrajoni dalam pemilihan legislatif DPR RI dapat dilihat pada table 2 di bawah ini:

\section{Tabel 2. Kemenangan Lisda Hendrajoni pendekatan teori Marketing Politik Andrew} Lock \& Phil Harris

\section{Pemasaran Politik (political marketing) Andrew Lock \& Phil Harris diidentifikasikan kedalam 4P}

\section{Product (Produk)}

1. Konsep:

Memberikan bantuan kepada masyarakat melalui kegiatan sosial pada program dunsanak mambantu dunsanak (DMD)

2. Identitas ideologi:

Berasal dari partai pemenangan yaitu Partai Nasional Demokrat (NasDem)

3. Isu politik yang menghasilkan image:

Aktif dalam program DMD untuk membantu masyarakat serta dalam masa pileg lebih massif mencari dukungan dan mengumpulkan masyarakat.

\section{Price (Harga)}

1. Harga Ekonomi:

Pada saat kampanye biaya hanya lebih kepada pencetakan spanduk, baliho, billboard dan lain-lain

2. Harga Psikologis:

Dilihat dari popularitas dan elektabilitas semenjak aktif menjadi ketua PKK yang ada di Pesisir Selatan dan seorang Istri Bupati Pesisir Selatan yang aktif

3. Harga Citra Nasional:

Pelaksanaan program sosial yang dilakukan berupa program DMD (dunsanak mambantu dunsanak) untuk mendapatkan dukungan dari masyarakat dan membangun citra positif sehingga dirasakan oleh masyarakat yang berdampak pada mempertahankan suara pemilih bagi Lisda Hendrajoni di Pesisir Selatan maupun di Sumbar 1

\section{Promotion (Promosi)}

1. Pemilihan media kampanye: Spanduk, baliho Billboar, Stiker, Kalender dan Contoh surat suara

2. Spanduk dan baliho menjadi alat promosi yang paling efektif dalam berkampanye dan diberikan kepada masyarakat pendukungnya

3. Baliho disebar dan dipasang di

\section{Place (Penempatan)}

1. Komunikasi:

kalangan masyarakat di bawah garis kemiskinan

2. Daerah Pendistribusian:

Enam basis gerak tim kemenangan di daerah pemilihan Sumbar 1, yaitu Pesisir Selatan, Tanah Datar, Dharmasraya, Solok Selatan, Kota 
Zeri Milyuta Putra, Mohammad Isa Gautama Pemanfaatan Media Luar Ruang Sebagai Salah Satu Strategi Pemenangan Lisda Hendrajoni Dalam Pileg 2019 Dapil Sumbar 1: Kajian Sosiologi Komunikasi Politik

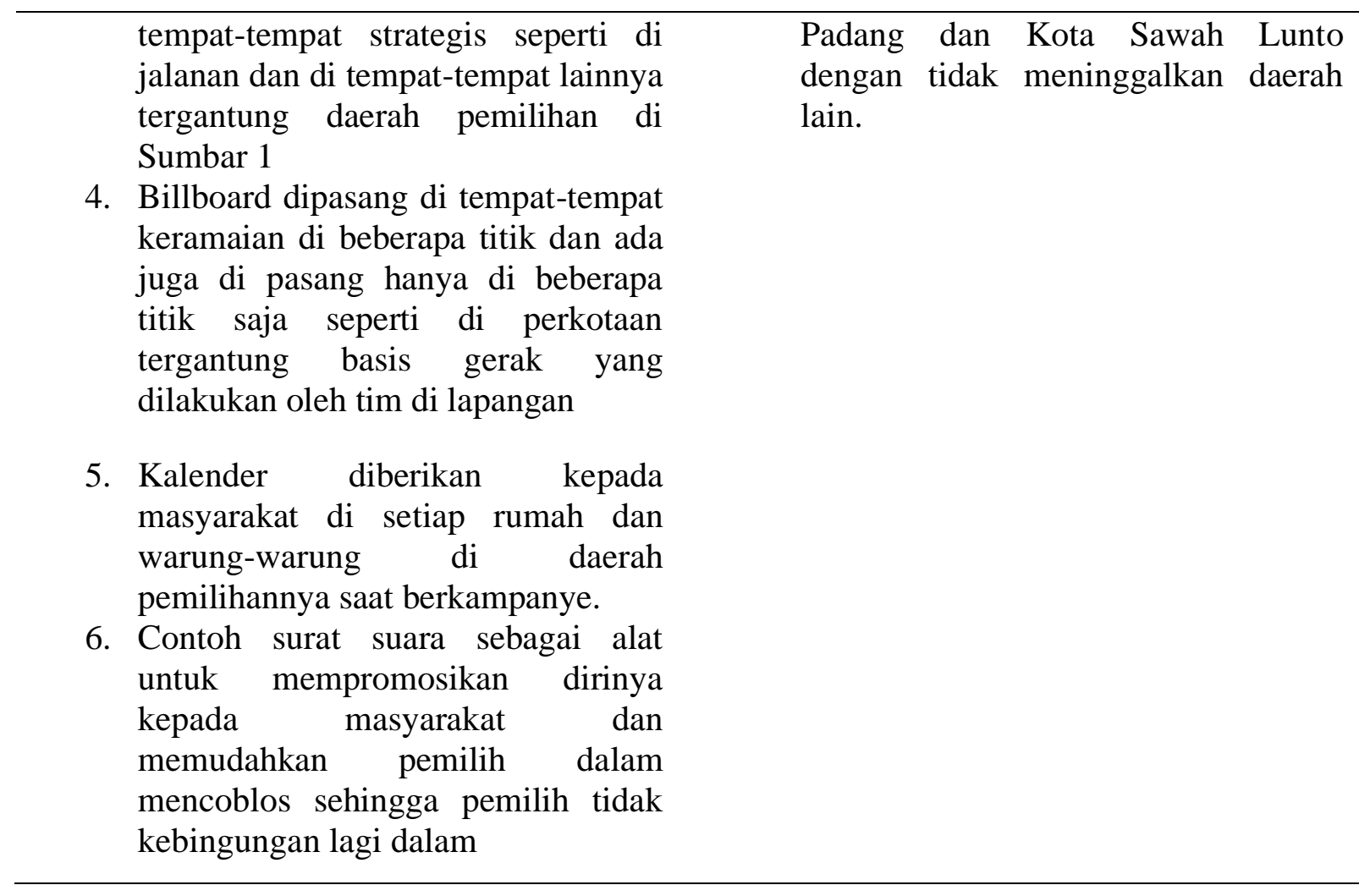

Berdasarkan pemaparan data yang didapat dan dengan pendekatan teoritis pemasaran politik (Political marketing) menurut Andrew Lock \& Phil Harris tersebut, maka keberhasilan Lisda Hendrajoni adalah dengan memanfaatkan jaringan yang dimiliki di daerah pemilihan Sumbar 1, jaringan tersebut adalah masyarakat di bawah garis kemiskinan dan jaringan partai serta tim kemenangan yang ada di Pesisir Selatan dan di Sumbar 1 luar Pesisir Selatan. Untuk menjaga suara dan dukungan dari konstituennya Lisda Hendrajoni melakukan sosialisasi kepada masyarakat baik secara langsung maupun melalui tim pemenangan, serta memberikan bantuan kepada masyarakat melalui program DMD (dunsanak mambantu dunsanak) kegiatan sosialnya dan Lisda Hendrajoni aktif dalam kegiatan PKKnya di Pesisir Selatan.

\section{Kesimpulan}

Berdasarkan hasil penelitian yang telah peneliti lakukan mengenai Pemanfaatan media luar ruang sebagai salah satu strategi pemenangan Lisda Hendrajoni dalam pileg 2019 dapil Sumbar 1 kajian Sosiologi Komunikasi Politik dapat disimpulkan bahwa : Pertama, strategi pemenangan Lisda Hendrajoni dalam pemilihan legislatif DPR RI periode 2019-2024 diantaranya dengan cara pendekatan terhadap masyarakat melalui program sosial yang dilakukan, pembagian tim kampanye dibagi atas dua daerah pemilihan yang ada di Sumbar 1 yaitu di Pesisir Selatan yang diketuai oleh Kristian Rinaldo dan Sumbar 1 diluar Pesisir Selatan diketuai oleh Jefri Hidayat. Kedua, media yang digunakan dalam kampanye pemenangan Lisda Hendrajoni pada saat jadi calon anggota legislatif diantaranya adalah pemakaian media luar ruang yang banyak ditemui dari kampanye Lisda Hendrajoni dalam pileg 2019 seperti spanduk, Baliho, Billboard, Kalender, Stiker, dan contoh surat suara. 
Ketiga, berdasarkan analisis teori Marketing Politik Andrew Lock \& Phil Harris terhadap pemenangan Lisda Hendrajoni dalam pemilihan legislatif DPR RI dapat di identifikasi kedalam 4P sebagai berikut: a) Product (Produk) meliputi Konsep yang memberikan bantuan kepada masyarakat melalui kegiatan sosial pada program dunsanak mambantu dunsanak (DMD), identitas ideology Lisda Hendrajoni berasal dari partai pemenangan yaitu partai Nasional Demokrat (NasDem), isu politik yang menghasilkan image diantaranya aktif dalam program DMD untuk membantu masyarakat serta dalam masa pileg lebih massif mencari dukungan dan mengumpulkan masyarakat; b) Price (Harga) meliputi harga ekonomi pada saat kampanye biaya lebih kepada pencetakan spanduk, baliho, billboard dan lain-lain, harga psikologis dilihat dari popularitas dan elektabilitas semenjak Lisda Hendrajoni aktif menjadi ketua PKK yang ada di Pesisir Selatan dan seorang istri Bupati Pesisir Selatan yang aktif, harga citra nasional dalam pelaksanaan program sosial yang dilakukan berupa program dunsanak mambantu dunsanak (DMD) untuk mendapatkan dukungan dari masyarakat dan membangun citra positif sehingga dirasakan oleh masyarakat yang berdampak pada mempertahankan suara pemilih bagi Lisda Hendrajoni di Pesisir Selatan maupun di Sumbar 1; c) Promotion (Promosi) dalam promosi Lisda Hendrajoni memilih media kampanye berupa spanduk, baliho, billboard, stiker, kalender, dan contoh surat suara; d) Place (Penempatan) melakukan komunikasi di kalangan masyarakat di bawah garis kemiskinan dan daerah pendistribusian ada enam basis gerak tim dan basis suara terbanyak di daerah pemilihan Sumbar 1 yaitu Pesisir Selatan, Tanah Datar, Dharmasraya, Solok Selatan, Kota Padang, dan Kota Sawah Lunto dengan tidak meninggalkan daerah lain.

\section{Daftar Pustaka}

Alkindi, F. (2019). Komunikasi Politik Calon Legislatif Partai Golongan Karya (Golkar) Dalam Pemenangan Pemilu Legislatif di Kota Pekanbaru Tahun 2014. Journal of Chemical Information and Modeling, 53(9), 1689-1699.

Andrew, L., \& Phil, H. (1996). Political marketing-vive la difference! European journal of marketing, 30(10-11), 14-24.

Darmawan, F. (2018). Modalitas Visual Komunikasi Politik Iklan Pilkada Kota Bandung 2018. Jurnal Komunikasi, 11(1), 56-65.

Haryono, D. (2019). Strategi KPU dalam meningkatkan partisipasi pemilih pada pemilihan Walikota dan Wakil Walikota Samarinda tahun 2015. Jurnal Administrative Reform (JAR), 6(2), 67-73.

Iman, S. (2018). Strategi Pemanfaatan Media Luar Ruang Dalam Kontestasi Politik Di Provinsi Lampung. Universitas Lampung.

Iqbal, L. M. (2012). Pelaksanaan Pull Marketing Jokowi Ahok dalam Pemenangan Pemilukada DKI Jakarta. Jurnal Komunikator, 5(2), 94-105.

Jaya, W., Cangara, H., \& Hasanuddin, U. (2015). Keberhasilan dan Kegagalan Strategi Komunikasi Kampanye Para Kandidat Dalam Perebutan Kursi Legislatif Dprd Kabupaten Barru Periode 2014-2019. Jurnal Komunikasi KAREBA, 4(3), 239-256.

Kriyantono, R. (2013). Manajemen Periklanan: Teori dan Praktik. Malang: Universitas Brawijaya Press.

Muljono, D. (2012). Buku Pintar Strategi Bisnis Koperasi Simpan Pinjam. Yogyakarta: Andi. Mulyana, D. (2010). Ilmu komunikasi: suatu pengantar: Suatu Pengantar (14 ed.). Bandung: Remaja Rosdakarya. 
O'Shaughnessy, N. (2001). The marketing of political marketing. European journal of marketing, 35(9-10), 1047-1057.

Suryatna, U. (2011). Pengaruh Terpaan Media Iklan Politik Terhadap Perilaku Pemilih Pemula. Jurnal Sosial Humaniora, 2(2), 134-144.

Sutarso, J. (2011). Pendekatan Pemasaran Politik (Political Marketing) Dalam Pemilihan Umum. KomuniTi, 3(1), 1-19.

Syamsuadi, A. (2013). Pemetaan Media Luar Ruang Pada Pelaksanaan Pemilihan Gubernur dan Wakil Gubernur Riau (Pilgubri) Tahun 2013 Di Kota Pekanbaru. Nakhoda: Jurnal Ilmu Pemerintahan, 12(20), 133-140.

Tjiptono, F. (2008). Strategi Pemasaran (3 ed.). Yogyakarta: Andi.

Yusuf, M. (2014). Metode Penelitian Kuantitatif. Kualitatif, dan Penelitian Gabungan. Jakarta: Prenadamedia Group. 